American Journal of Neuroscience 3 (1): 1-9, 2012

ISSN 1948-9900

C 2012 Science Publications

\title{
Diphenylhydantoin Promotes Proliferation in The Subventricular Zone and Dentate Gyrus
}

\author{
${ }^{1,2}$ Alma Y. Galvez-Contreras, ${ }^{2}$ Rocio E. Gonzalez-Castaneda, \\ ${ }^{2}$ Sonia Luquin, ${ }^{1}$ Jorge Guzman-Muniz, ${ }^{1}$ Norma A. Moy-Lopez, \\ ${ }^{2}$ Rodrigo Ramo Zuniga and ${ }^{1,2}$ Oscar Gonzalez-Perez \\ ${ }^{1}$ Laboratory of Neuroscience, Facultad de Psicologia, \\ Universidad de Colima (UCOL), Colima, 28040, Mexico \\ ${ }^{2}$ Department of Neuroscience, Centro Universitario de Ciencias de la Salud, \\ Universidad de Guadalajara, Jalisco 44340, Mexico
}

\begin{abstract}
Problem statement: Diphenylhydantoin (phenytoin) is an antiepileptic drug that generates hyperplasia in some tissue by stimulating Epidermal Growth Factor (EGFR) and Platelet-Derived Growth Factor beta (PDGFR- $\beta$ ) receptors and by increasing serum levels of basic fibroblast growth factor (bFGF, FGF2 or FGF- $\beta$ ). Neural stem cells in the adult brain have been isolated from three regions: the Subventricular Zone (SVZ) lining the lateral wall of the lateral ventricles, the Subgranular Zone (SGZ) in the dentate gyrus at the hippocampus and the Subgranular Zone (SZC) lining between the hippocampus and the corpus callosum. Neural stem cells actively respond to bFGF, PDGFR- $\beta$ or EGF by increasing their proliferation, survival and differentiation. The aim of this study was to evaluate the effect of phenytoin on proliferation and apoptosis in the three neurogenic niches in the adult brain. Approach: We orally administrated phenytoin with an oropharyngeal cannula for 30 days: $0 \mathrm{mg} \mathrm{kg}^{-1}$ (controls), 1, 5, 10, 50 and $100 \mathrm{mg} \mathrm{kg}^{-1}$. To label proliferative cells, three injections of $100 \mathrm{mg} \mathrm{kg}^{-1}$ of BrdU was administrated every $12 \mathrm{~h}$. Immunohistochemistry against BrdU or Caspase-3 active were performed to determine the number of proliferative or apoptotic cells. Results: Our results showed that phenytoin induces proliferation in the SVZ and the SGZ in a dosedependent manner. No statistically significant effects on cell proliferation in the SCZ neither in the apoptosis rate at the SVZ, SGZ and SCZ were found. Conclusion: These data indicate that phenytoin promotes a dose-dependent proliferation in the SVZ and SGZ of the adult brain. The clinical relevance of these findings remain to be elucidated.
\end{abstract}

Key words: Epidermal Growth Factor (EGFR), Subventricular zone (SVZ), Subgranular Zone (SGZ), neural stem cells, Platelet-Derived Growth Factor beta (PDGFR- $\beta$ )

\section{INTRODUCTION}

Diphenylhydantoin Phenylhydantoin) also known as phenytoin is an effective anticonvulsant in tonic-clonic epilepsy (Cornacchio et al., 2011). Voltaged-gated channels are involved in the epilepsy pathophysiology (Abuhamed $e t$ al., 2008). The primary target of phenytoin in depolarizing neurons is voltage-dependent sodium channels, where phenytoin blocks sodium influx, reducing neuronal excitability and limiting the spread of electrical activity of seizures (Shaw et al., 2007). Other mechanisms possibly contributing to the antiepileptic activity of phenytoin include a suppression of sodium action potentials by stimulating the sodium pump, inhibition of calcium influx in neurons, blockage of ionotropic receptors for glutamate and enhancement of GABA neurotransmission (Escueta and Appel, 1971; Kaindl et al., 2006; Yang et al., 2007). Thus, its safety profile and ease of use make phenytoin an attractive drug for the seizure prophylaxis and the control of status epilepticus. Some of side effects of phenytoin include gingival hyperplasia (Eyer et al., 2008), hypertrichosis (hirsutism) (Vivard et al., 1989), acne (Jenkins and Ratner , 1972), cerebellar atrophy (Ohmori et al., 1999), hyperglycemia (Yang et al., 2007) and others.

Recent evidence indicates that phenytoin promotes proliferation of primary progenitors in several tissues,

Corresponding Author: Oscar Gonzalez-Perez, Laboratory of Neuroscience, Facultad de Psicologia,

Universidad de Colima (UCOL), Colima, 28040, Mexico Tel: +52 (312) 316-1091 
such as: skin (Swamp et al., 2004), heart (Zhou et al., 2006), bone (Lau et al., 1995) and oral mucosa (Arya and Gulati, 2012; Sano et al., 2004). Phenytoin-induced tissue hyperplasia seems to be mediated by increasing levels of connective tissue growth factor (CCN2/CTGF), transforming growth factor $\beta 1$ (TGF$\beta 1$ ) (Kantarci et al., 2007; Kuru et al., 2004), mRNA of Platelet-Derived Growth Factor (PDGF- $\beta$ ) (Dill et al., 1993; Iacopino et al., 1997), Fibroblast Growth Factor type-2 (FGF-2) (Saito et al., 1996; Sasaki and Maita, 1998; Turan et al., 2004) and Epidermal Growth Factor Receptors (EGFR) (Modeer and Andersson, 1990; Soory and Kasasa, 1997).

In the adult mammalian brain, there are neural stem cells that produce new neurons and oligodendrocytes (Mackay-Sim, 2010). These multipotent progenitors are located in restricted regions: the Subventricular Zone (SVZ), lining the lateral wall of the lateral ventricle (Garcia-Verdugo et al., 1998), the Subgranular Zone (SGZ) located in the dentate gyrus at the hippocampus (Seri et al., 2004) and the Subcallosal Zone (SCZ), lining between the hippocampus and the corpus callosum (Seri et al., 2006). Neural stem cells and intermediate progenitors in these regions express a wide variety of tyrosine kinase receptors, such as PDGFR $\alpha$, EGFR, TGF $\beta$ receptor, FGFR and others (Danilov et al., 2009; Doetsch et al., 2002; Frinchi et al., 2008). Proliferation of neural stem cells is modulated by tyrosine kinase receptors (Aguirre et al., 2007; 2010; Ayuso-Sacido et al., 2010; Balu and Lucki, 2009; Ming and Song, 2005). Thus, neural progenitor cells may be a pharmacological target for phenytoin effects. The aim of this study was to analyze whether phenytoin promoted proliferation or apoptosis in the SVZ, the SGZ and the SCZ. Our findings indicate that phenytoin induces a dose-dependent proliferative effect in the SVZ and SGZ. No changes were observed in apoptosis. These results may be of clinical relevance because neural stem cells have been successfully isolated in the adult human brain (Sanai et al., 2004) and phenytoin is a drug commonly used in epileptic patients.

\section{MATERIALS AND METHODS}

Animal care and tissue processing: All animal procedures followed the Committee on Animal Research guidelines in the University of Colima. Adult (P60) Balb/C mice were sacrificed by an overdose of pentobarbital (100 mg kg-1 body weight) before transcardial perfusion. For light microscopy analysis, mice ( $\mathrm{n}=5$ per group) were perfused with $4 \%$ Paraformaldehyde (PFA) dissolved in $0.1 \mathrm{M}$ phosphate buffer and the brains were post-fixed overnight at $4^{\circ} \mathrm{C}$ in the same fixative. Then, $40-\mu \mathrm{m}$ thick coronal sections were cut with a vibratome.

Phenytoin administration: 5, 5-Diphenylhydantoin (Sigma, Cat. No. D4505) re-suspended in distilled water (vehicle) or vehicle alone were orally administrated for 30 days with an oropharyngeal cannula. We used the following doses $(n=5$ animals per dose): $0,1,5,10,50$ and $100 \mathrm{mg} \mathrm{kg}^{-1}$.

Bromodeoxiuridine (BrdU) administration: BrdU is a synthetic thymidine that incorporates into DNA during the S-phase of the cell cycle (Cameron and McKay, 2001; Falconer and Galea, 2003; Taupin, 2007). To label all progeny derived from the SVZ, SGZ and SCZ precursors, we injected 3 doses of $100 \mathrm{mg}$ $\mathrm{kg}^{-1}$ i.p. BrdU every 12h (Cameron and McKay, 2001; Gonzalez-Perez et al., 2011) before animals' sacrifice.

Immunohistochemistry (IHC): Sections were then incubated in pre-warmed (at $37^{\circ} \mathrm{C}$ ) $2 \mathrm{~N} \mathrm{HCl}$ for $30 \mathrm{~min}$. Then, a single wash with $0.1 \mathrm{M}$ borate buffer $(\mathrm{pH}=$ 8.5 ) for $10 \mathrm{~min}$ was utilized to neutralize $\mathrm{HCl}$. Then, samples were rinsed $(10 \mathrm{~min} \times 3)$ in $0.1 \mathrm{M}$ buffer Phosphate Buffer Saline (PBS). After peroxidase inactivation with $30 \% \mathrm{H}_{2} \mathrm{O}_{2}$ for $30 \mathrm{~min}$, sections were blocked in $0.1 \mathrm{M}$ PBS containing $0.1 \%$ Triton-X and $10 \%$ of normal goat serum for $1 \mathrm{~h}$ at room temperature, sections were incubated overnight at $4{ }^{\circ} \mathrm{C}$ in primary antibodies diluted in blocking solution. The following primary antibodies were used: rat monoclonal to BrdU (1:500; Accurate Chemical OBT0030) or mouse IgG anti-Caspase-3 active (Casp3; Imgenex IMG-144A) dilution 1:800. Sections were washed in 0.1M PBS, incubated in blocking solution with the appropriate biotinylated secondary antibody (1:200; Vector Laboratories, Burlingame, CA) for $1 \mathrm{~h}$ at room temperature, incubated in $\mathrm{ABC}$ peroxidase kit (Vector Laboratories, Burlingame, CA) for $1 \mathrm{~h}$ and revealed with $0.03 \%$ diaminobenzidine and $0.01 \% \quad \mathrm{H}_{2} \mathrm{O}_{2}$. Controls in which primary antibodies were omitted showed no detectable staining.

Quantification: To quantify the number of BrdUpositive or Casp3-positive cells, we analyzed at least ten $40-\mu \mathrm{m}$ sections randomly selected, 160- $\mu \mathrm{m}$ apart (n $=5$ animals per group). For SVZ quantifications, the number of BrdU+ or Casp3+ cells was quantified within $100 \mu \mathrm{m}$ from the ependymal layer along the ventricle per every section. For SGZ quantifications, the number of immuno-positive cells found along the dentate gyrus was quantified in every section. The SCZ is a caudal extension of the SVZ that is no longer 
associated to an open ventricle (Seri et al., 2006). For SCZ quantifications, the number of labeled cells around the ependymal cell layer was counted in all SCZ cavitations per each section. All the quantifications were made under a Zeiss microscope (Axio Observer D2, Germany) using a 100X oil-immersion objective (area of the microscopic field $=0.025 \mathrm{~mm}^{2}$ ). All quantifications were done by a researcher 'blinded' to group assignment. All data were expressed as means \pm standard deviation. We used one-way ANOVA followed by the Tukey's post-hoc test. The $\mathrm{p}<0.05$ value was chosen to determine significant differences.

\section{RESULTS}

Phenytoin administration was well-tolerated and no side effects were observed at any of doses used throughout the study. We recorded the weight gain during phenytoin administration (Fig. 1) and did not find significant differences between the control-vehicle group vs. the phenytoin groups (ANOVA-Tukey, $\mathrm{P}=0.63$ ). This suggested that the potential sedative effects of phenytoin did not change the body development of animals.

The subventricular zone: To characterize the effect of different concentrations of phenytoin on SVZ precursors, we delivered different doses of phenytoin $\left(0,1,5,10,50\right.$ and $\left.100 \mathrm{mg} \mathrm{kg}^{-1}\right)$ and administrated 3 injections of $100 \mathrm{mg} \mathrm{kg}^{-1}$ of BrdU before sacrifice. After 30 days of phenytoin administration, we found no statistically significant differences in the number of BrdU+ cells in the group of $1 \mathrm{mg} \mathrm{kg}^{-1}$ of phenytoin (22.00 \pm 0.55 cells per field) as compared to the control group (16.62 \pm 2.07 cells per field) (Fig. 2). However statistically significant differences were found with the doses of $5 \mathrm{mg} \mathrm{kg}^{-1}$ (27.58 \pm 1.56 cells per field), 10 $\mathrm{mg} \mathrm{kg}$ (28.42 \pm 2.09 cells per field), $50 \mathrm{mg} \mathrm{kg}$ $\left(27.42 \pm 2.11\right.$ cells per field) and $100 \mathrm{mg} \mathrm{kg}^{-1}$ of phenytoin $(24.90 \pm 1.11$ cells per field; $\mathrm{p}<0.05$, ANOVA-Tukey's test) as compared to controls. Interestingly, upon $10 \mathrm{mg} \mathrm{kg}^{-1}$ of phenytoin no further changes in proliferation were observed.

To analyze the apoptosis rate in the SVZ, we quantified the number of CASP3+ cells in this region. In all cases, we did not find statistically significant differences among groups: the control group (5.27 \pm 1.36 cells per field), $1 \mathrm{mg} \mathrm{kg}^{-1}$ (5.06 \pm 0.96 cells per field), 5 $\mathrm{mg} \mathrm{kg}$ (5.37 \pm 0.82 cells per field), $10 \mathrm{mg} \mathrm{kg}^{-1}$ (5.30 \pm 1.22 cells per field), $50 \mathrm{mg} \mathrm{kg}^{-1}(6.83 \pm 1.85$ cells per field) and $100 \mathrm{mg} \mathrm{kg}^{-1}$ of phenytoin $(13.14 \pm 3.45$ cells per field; ANOVA-Tukey). Taken together these data suggests that phenytoin promotes proliferation of SVZ neural progenitors in a dose-dependent manner without changing the apoptosis rate in this region.

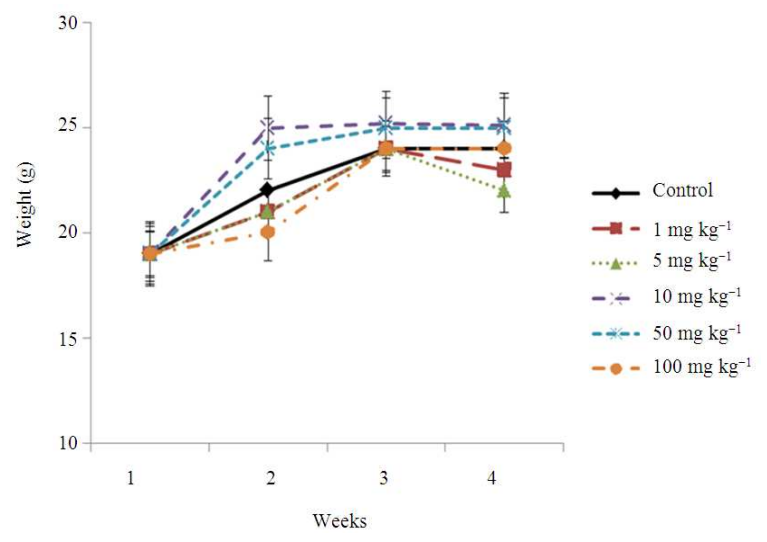

Fig. 1: Weight gain curve upon phenytoin administration. No statistically significant differences were found between the controlvehicle group vs. the phenytoin groups (ANOVA-Tukey, $\mathrm{P}=0.63$ ). The lines represent the mean \pm standard deviation of each group

The subgranular zone: To characterize the effect of different concentrations of phenytoin on SGZ precursors, we orally delivered $0,1,5,10,50$ and $100 \mathrm{mg} \mathrm{kg}^{-1}$ of phenytoin per day and administrated BrdU before sacrifice. At day 30th, we quantified the number of BrdU+ cells in the dentate gyrus in the hippocampus (Fig. 3). We found an increase in the number of BrdU+ cells in the SGZ with the dose of $10 \mathrm{mg} \mathrm{kg}^{-1}$ of phenytoin (5.87 \pm 0.34 cells per field) as compared to controls (4.01 \pm 0.26 cells per field; $\mathrm{p}<0.05$, ANOVA-Tukey). Interestingly, no significant differences were observed with the doses of $1 \mathrm{mg}$ ( $4.62 \pm 0.39$ cells per field), $5 \mathrm{mg}$ $\mathrm{kg}^{-1}$ (4.46 \pm 0.32 cells per field), $50 \mathrm{mg} \mathrm{kg}^{-1}$ (4.04 \pm 0.24 cells per field) $100 \mathrm{mg} \mathrm{kg}^{-1}(4.39 \pm 0.20$ cells per field) of phenytoin. We then quantify the number of CASP3+ cells in the SGZ. Our findings indicate that there are not statistical significant differences among groups: the control group $(0.04 \pm 0.01$ cells per field $), 1$ $\mathrm{mg} \mathrm{kg}(0.08 \pm 0.02$ cells per field $), 5 \mathrm{mg} \mathrm{kg}^{-1}$ $\left(0.07 \pm 0.02\right.$ cells per field), $10 \mathrm{mg} \mathrm{kg}^{-1}(0.05 \pm 0.02$ cells per field), $50 \mathrm{mg} \mathrm{kg}^{-1}(0.05 \pm 0.01$ cells per field) and $100 \mathrm{mg} \mathrm{kg}^{-1}$ of phenytoin $(0.09 \pm 0.02$ cells per field; ANOVA-Tukey). These results suggest that only the dose of $10 \mathrm{mg} \mathrm{kg}$ of phenytoin promotes proliferation of SGZ progenitors and that this drug did not change the apoptosis rate in this region.

The subcallosal zone: We finally characterize the effect of different concentrations of phenytoin on SCZ neural precursors. At day $30^{\text {th }}$, we quantified the number of BrdU+ cells in the SCZ (Fig. 4). 


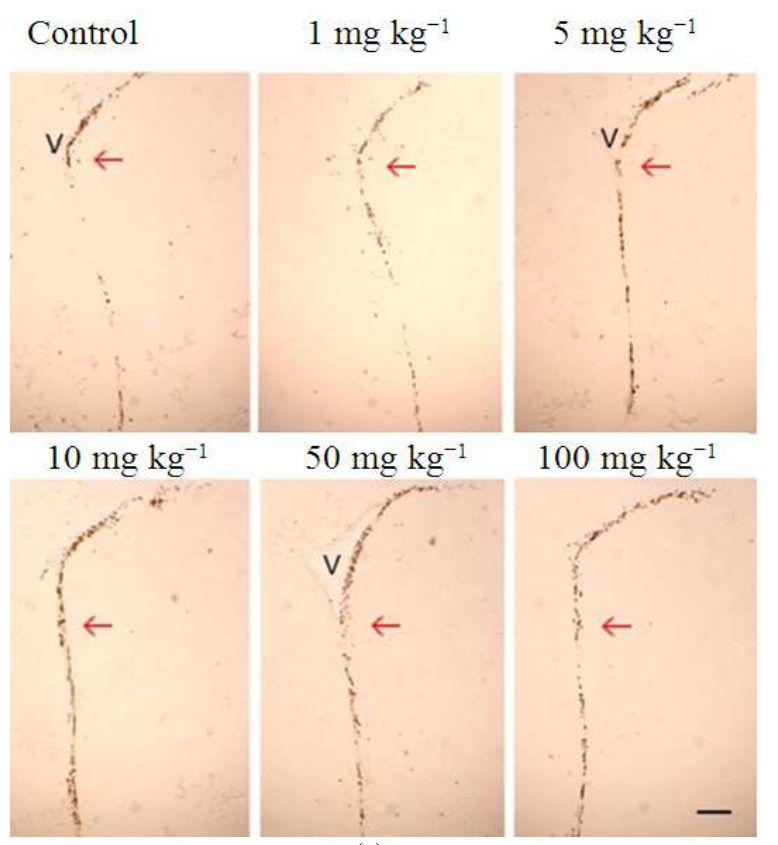

(a)

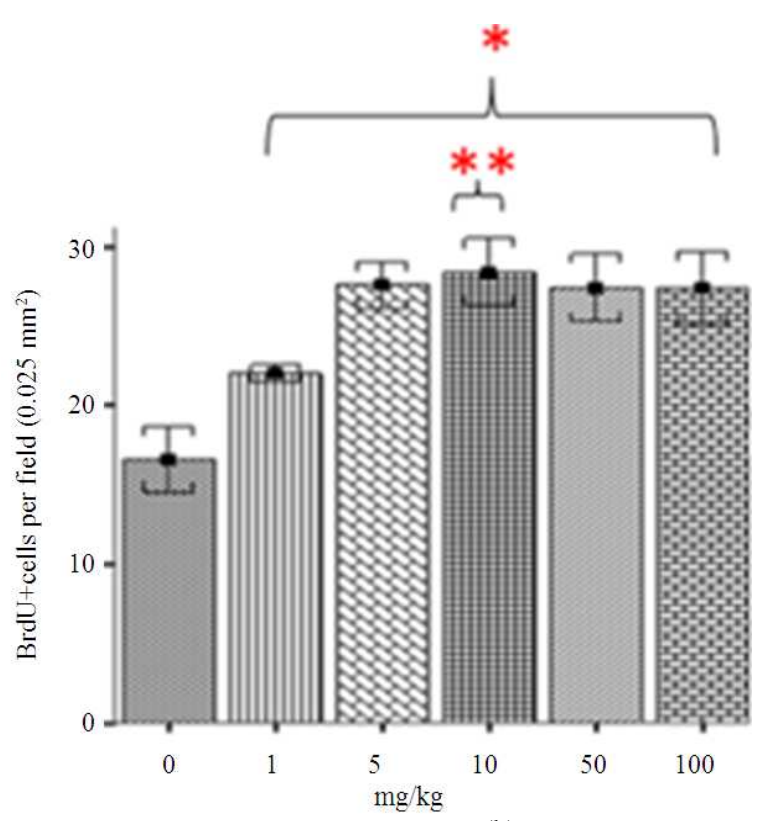

(b)

Fig. 2: BrdU+ cells in the adult SVZ in mice after 30 days of phenytoin or vehicle administration (A). The quantification of BrdU+ cells is summarized in the graph (B). The bars represent the mean \pm standard deviation. Arrows indicate some BrdU+ cells. V: ventricle; $(*) \mathrm{p}=0.05$ ANOVA-Tukey; $(* *) \mathrm{p}=0.01$ ANOVA-Tukey. Scale bar $=200 \mu \mathrm{m}$

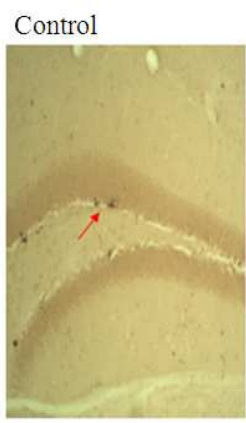

$10 \mathrm{mg} \mathrm{kg}^{-1}$

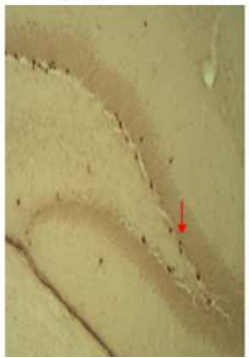

$1 \mathrm{mg} \mathrm{kg}^{-1}$

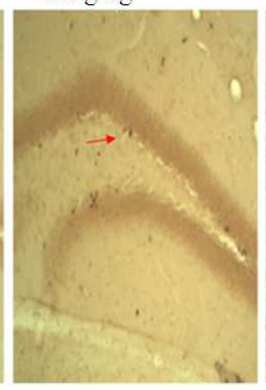

$50 \mathrm{mg} \mathrm{kg}^{-1}$

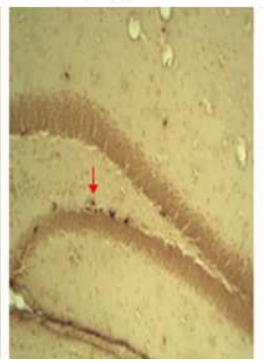

(a)
$5 \mathrm{mg} \mathrm{kg}^{-1}$

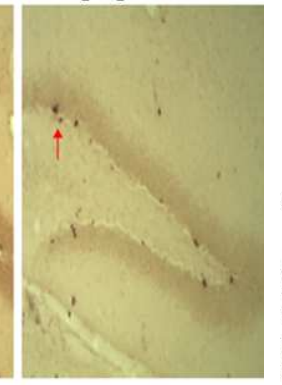

$100 \mathrm{mg} \mathrm{kg}-1$

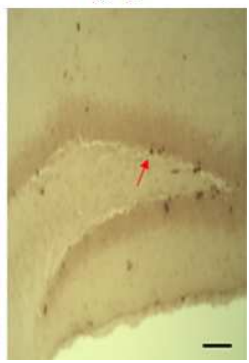

-

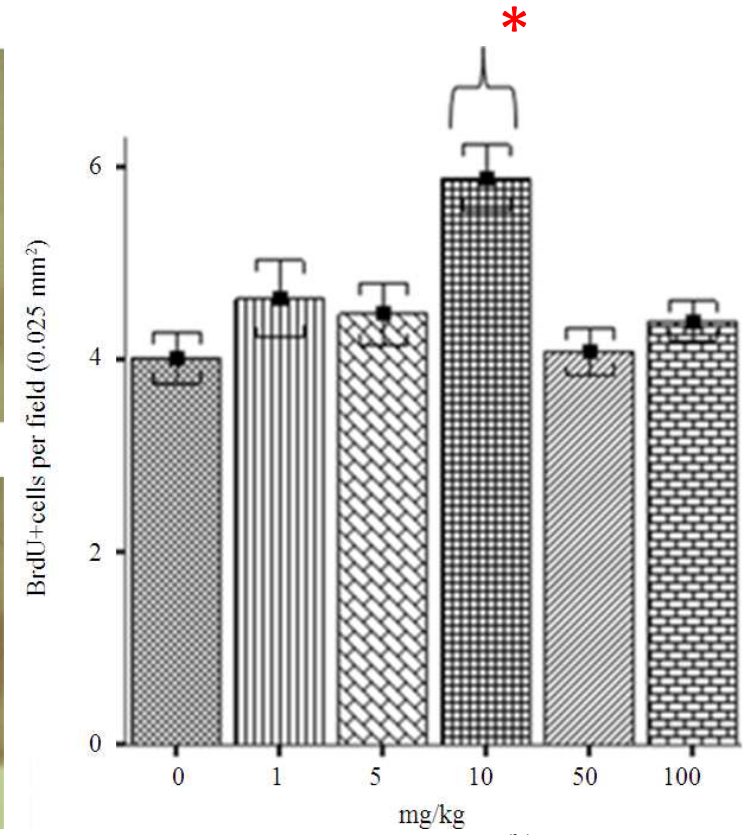

(b)

Fig. 3: BrdU+ cells in the adult SGZ after 30 days of phenytoin or vehicle administration (A). The quantification of BrdU+ cells is summarized in the graph (B). The bars represent the mean \pm standard deviation. Arrows indicate some BrdU+cells. $\left.{ }^{*}\right) \mathrm{p}=0.05$ ANOVA-Tukey. Scale bar $=100 \mu \mathrm{m}$ 


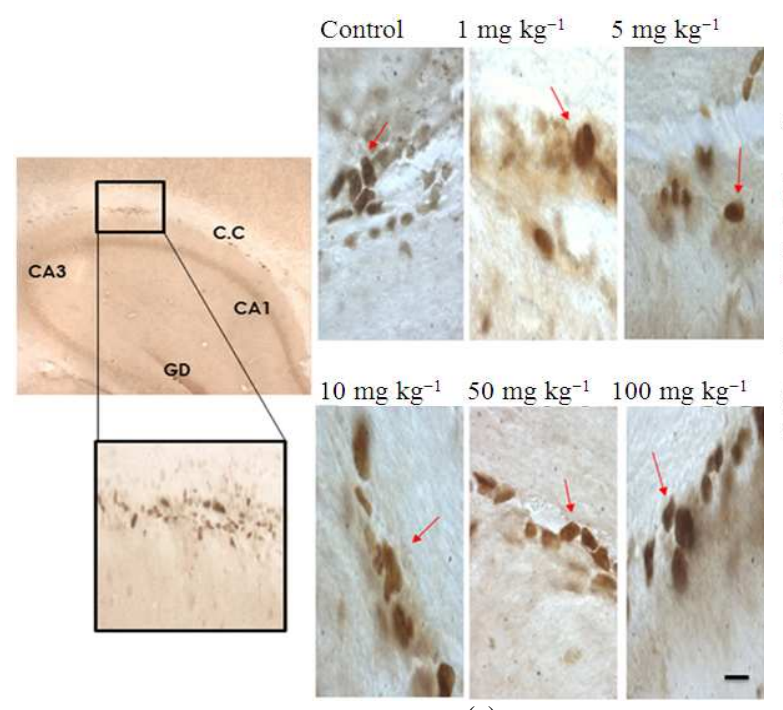

(a)

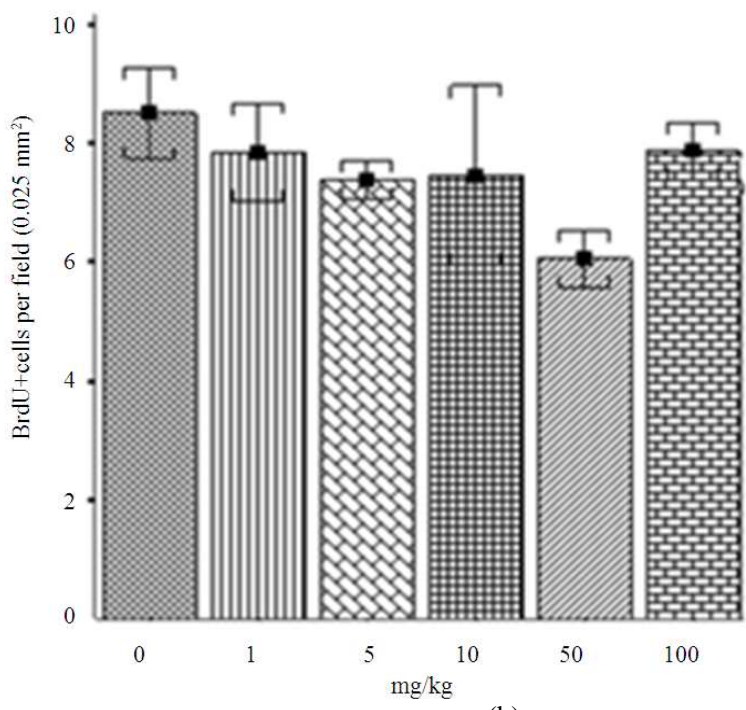

(b)

Fig. 4: BrdU+ cells in the adult SCZ after 30 days of phenytoin or vehicle administration (A). The quantification of BrdU+ cells is summarized in the graph (B). The bars represent the mean \pm standard deviation. Arrows indicate some BrdU+ cells. No statistically significant differences were found among groups (ANOVATukey). Scale bar $=10 \mu \mathrm{m}$

We did not find significant differences in the number of BrdU+ cells among groups: the control group $(8.4 \pm 0.76$ cells per field), $1 \mathrm{mg} \mathrm{kg}^{-1}$ (7.8 \pm 0.82 cells per field), $5 \mathrm{mg}$ $\mathrm{kg}^{-1}\left(7.37 \pm 0.31\right.$ cells per field), $10 \mathrm{mg} \mathrm{kg}^{-1}(7.45 \pm 1.50$ cells per field), $50 \mathrm{mg} \mathrm{kg}^{-1}(6.04 \pm 0.47$ cells per field) and $100 \mathrm{mg} \mathrm{kg}^{-1}$ of phenytoin ( $7.88 \pm 0.48$ cells per field). The analysis of CASP3 + cells in this region did not show statistical significant differences: the control group $(0.04 \pm 0.02$ cells per field $), 1 \mathrm{mg} \mathrm{kg}^{-1}(0.03 \pm 0.01$ cells per field), $5 \mathrm{mg} \mathrm{kg}^{-1}(0.04 \pm 0.02$ cells per field), $10 \mathrm{mg}$ $\mathrm{kg}^{-1}(0.03 \pm 0.01$ cells per field $), 50 \mathrm{mg} \mathrm{kg}^{-1}(0.04 \pm 0.03$ cells per field) and $100 \mathrm{mg} \mathrm{kg}^{-1}$ of phenytoin $(0.01 \pm 0.01$ cells per field; ANOVA-Tukey). Taken together, our data suggest that phenytoin cannot induce changes in proliferation and apoptosis of the SCZ neural progenitors.

\section{DISCUSION}

In this study, we show that: (1) Different doses of phenytoin did not alter weight gain in adult mice; (2) Phenytoin induces proliferation in the SVZ and the SGZ in a dose-dependent manner; (3) Phenytoin has no significant effect on the proliferation rate in the SCZ; and (4) No statistically significant changes on the apoptosis rate in any of the analyzed regions are induced by phenytoin. Taken together, these data indicate that phenytoin promotes proliferation in the main neurogenic niches of the adult brain in vivo without changing the apoptosis rate.
As described above, our findings indicated that different doses of phenytoin did not alter weight gain. Similar findings have been reported in Sprague Dawley ${ }^{\circledR}$ rats (Mowery et al., 2008). However, another report indicated that phenytoin administration at earlypostnatal stages reduced food intake and weight gain (Mowery et al., 2008). These changes were reversible when phenytoin supplementation was suspended or when administrated at older development stages (Mowery et al., 2008; Okada et al., 1997; 2001). Hence, this evidence suggests that the metabolism of phenytoin or its cellular receptors vary according to the age stages (Ogura et al., 2002).

In our study, we quantified the number of BrdU+ cells along the SVZ. BrdU is a reliable proliferation marker that incorporates DNA during $\mathrm{S}$ phase and can be detected by immunohistochemistry (Kee et al., 2002; Taupin, 2007). The protocol and dose of BrdU administration used in this study has shown to reduce the false positive and lacks significant side effects (Cameron and McKay, 2001). Our findings indicated that the phenytoin-induced proliferative effect is observed from the dose of $5 \mathrm{mg} \mathrm{kg}^{-1}$, but it reaches a plateau at $10 \mathrm{mg} \mathrm{kg}^{-1}$ of phenytoin in the SVZ. Interestingly, in the SGZ this drug shows proliferative effects only with $10 \mathrm{mg} \mathrm{kg}^{-1}$ of phenytoin. Proliferative effects of phenytoin have been described in several tissues, such as: Skin (Swamy et al., 2004), cardiomyocytes (Zhou et al., 2006), bone (Lau et al. 1995), bone marrow stem cells (Ohta et al., 1995) and oral mucosa (Sano et al., 2004). These effects seem to 
be mediated by increasing c-jun levels and suppression of p44/42, which indicates that phenytoin can modify MAPK signaling pathway (Zhao et al., 2003).

In addition, proliferative effects of phenytoin can be mediated by increasing levels of growth factors and cytokines (Okada et al., 2001), which modify the proliferation rate, apoptosis, migration and differentiation of neural stem cells (AlvarezPalazuelos et al., 2011; Gonzalez-Perez et al., 2010). Oral administration of phenytoin in patients has shown to increase levels of osteocalcin, also known as Bone Gamma-Carboxyglutamic Acid-Containing Protein (BGLAP) (Koyama et al., 2000; Lau et al., 1995) and basic Fibroblast Growth Factor (FGF-2) (Saito et al., 1996; Sasaki and Maita, 1998; Turan et al., 2004). Other molecules associated with the phenytoin-induced proliferation are: bone morphogenetic protein 4 (BMP-4), endothelin 1 and Transforming Growth Factor $\beta$ (TGF- $\beta$ ); (Koyama et al., 2000; Nakade et al., 1996; Sano et al., 2004).

Phenytoin is also a competitive binding agonist of the Epidermal Growth Factor Receptor (EGFR) (Grenader et al., 2007) and increases the expression of EGFR (Modeer and Andersson, 1990). EGFR are highly expressed in the SVZ precursors (Doetsch et al., 2002) and control proliferation and migration of neural precursors in the adult SVZ (Gonzalez-Perez, 2010; Gonzalez-Perez et al., 2009). EGFR mitogenic effects are mediated through MAPK, Akt and IP3 downstream pathways (Gonzalez-Perez and Alvarez-Buylla, 2011; Jorissen et al., 2003). PI3K/AKT is involved in survivor and matures of oligodendrocytes in the early development of the central nervous system (Flores et al., 2008). Activation of EGFR activates PI3K/Akt signal transduction pathway that positively regulates Glycogen Synthase Kinase $3 \beta$ (GSK-3 $\beta$ ) (Zhang et al., 2002). In addition, EGFR stimulation of SVZ adult precursors promotes oligodendrogenesis and arrests neurogenesis (Gonzalez-Perez, 2010; Gonzalez-Perez and Alvarez-Buylla, 2011; Gonzalez-Perez et al., 2009). Since EGFR signaling has been related to brain tumor progression (Jorissen et al., 2003), the role of phenytoin in tumorigenesis remains to be elucidated.

This study indicates that cell proliferation in the dentate gyrus were only noticeable with the dose of 10 $\mathrm{mg} \mathrm{\textrm {kg } ^ { - 1 }}$ of phenytoin, whereas no significant differences were observed in the SCZ. Interestingly, in our study higher doses of phenytoin induced no proliferation in neuronal SGZ precursors. We hypothesize that regional differences may be due to different levels of EGFR expression in the neural precursor of the SGZ and SCZ as compared to the SVZ (Seri et al., 2004; 2006). Therefore, phenytoin may be exerting some differential proliferative effect on these regions. Dual effects of phenytoin have been previously described that, at certain doses, it reduce cerebral monoamines (Vazquez et al., 2003). On this regard, serotonin modulates the proliferation of SGZ precursors (Sahay and Hen, 2008; Warner-Schmidt and Duman, 2006). Therefore, high doses of phenytoin can reduce the levels of serotonin (Okada et al., 1997) that, in turn, decrease cell proliferation into the SGZ. Remarkably, another anticonvulsant drug, magnesium valproate, has shown either proliferation or apoptosis, depending on the dose used on microglial cells and neuronal precursors (Dragunow et al., 2006). Phenytoin also increases the levels of Adrenocorticotropic Hormone (ACTH) and corticosterone (Okada et al., 2001), probably mediated by the P450 cytochrome enzyme system (Putignano et al., 1998), which reduce proliferation of SGZ precursors (Gonzalez-Perez et al., 2011; Nichols et al., 2005). Therefore, high levels of glucocorticoids induced by phenytoin may also modify the proliferation rate of neural precursors in the dentate gyrus.

In addition, our data indicate that phenytoin did not induce changes in the number of CASP3+ cells in any of the analyzed regions, which suggest that the increase in the number of BrdU+ cells is not due to a reduction in apoptosis rate. Similar findings have been reported in epithelial cells from oral mucosa (Kantarci et al., 2007). However, other anticonvulsants have shown to induce apoptosis in microglia, which suggest that apoptosis induction is probably related to intrinsic drug metabolism (Dragunow et al., 2006).

There are several questions that remain to be elucidated, such as: (1) what kind of cell types proliferate in the SVZ and the SGZ; (2) Do these cells remain in the brain parenchyma; (3) Do they differentiate in the brain parenchyma; If so, (3) Do they play a functional role into the brain. In addition, it would be interesting to test the phenytoin in experimental models of disease (Anderson et al., 2008; Jqamadze et al., 2012). Therefore further studies are needed to address these questions

\section{CONCLUSION}

Phenytoin induces cell proliferation of neural precursors in the SVZ in the forebrain and the SGZ in the dentate gyrus in a dose-dependent manner, without changing apoptosis rates of these neurogenic niches. Whether phenytoin may promote proliferation in the human brain remains to be elucidated

\section{ACKNOWLEDGEMENT}

A.Y.G-C was supported by CONACyT's doctoral fellowship (214282). O.G-P was supported by grants from the Consejo Nacional de Ciencia y Tecnologia (CONACyT; CB-2008-101476) and The National 
Institute of Health and the National Institute of Neurological Disorders and Stroke (NIH/NINDS; R01 NS070024).

\section{REFERENCES}

Abuhamed, M., X. Bo, K. Xia, Y. Fang and L. Long, 2008. Voltaged-gated channels as causative agents for epilepsies. Am. J. Immunol., 4: 43-50. DOI: 10.3844/ajisp.2008.43.50

Aguirre, A., J.L. Dupree, J.M. Mangin and V. Gallo 2007. A functional role for EGFR signaling in myelination and remyelination. Nat. Neurosci., 10: 990-1002. PMID: 17618276

Aguirre, A., M.E. Rubio and V. Gallo 2010. Notch and EGFR pathway interaction regulates neural stem cell number and self-renewal. Nature, 467: 323327. PMID: 20844536

Alvarez-Palazuelos, L.E., M.S. Robles-Cervantes, G. Castillo-Velazquez, M. Rivas-Souza and R.E. Gonzalez-Castaneda et al., 2011. Regulation of neural stem cell in the human SVZ by trophic and morphogenic factors. Curr. Signal Transduct. Ther., 6: 320-326. PMID: 22053150

Anderson, P., Hooker, B. and R.M. Herbert, 2008. Bridgin from cells to cognition in autism pathoshysiology: Biological pathways to detective brain function and plasticity. Am. J. Biochem. Biotechnol., $\quad 4$ : 167-176. DOI 10.3844/ajbbsp.2008.167.176

Arya, R. and S. Gulati, 2012. Phenytoin-induced gingival overgrowth. Acta Neurol. Scand, 125: 149-155. PMID: 21651505

Ayuso-Sacido, A., J.A. Moliterno, S. Kratovac, G.S. Kapoor and D.M. O'Rourke et al., 2010. Activated EGFR signaling increases proliferation, survival and migration and blocks neuronal differentiation in post-natal neural stem cells. J. Neurooncol., 97: 323-337. PMID: 19855928

Balu, D.T. and I. Lucki, 2009. Adult hippocampal neurogenesis: Regulation, functional implications and contribution to disease pathology. Neurosci. Biobehav. Rev., 33: 232-252. PMID: 18786562

Cameron, H.A. and R.D. McKay, 2001. Adult neurogenesis produces a large pool of new granule cells in the dentate gyrus. J. Comput. Neurol., 435: 406-417. PMID: 11406822

Cornacchio, A.L., J.G. Burneo and C.E. Aragon, 2011. The effects of antiepileptic drugs on oral health. J. Can Dent. Assoc., 77: b140- b140. PMID: 22260801

Danilov, A.I., W. Gomes-Leal, H. Ahlenius, Z. Kokaia and E. Carlemalm et al., 2009. Ultrastructural and antigenic properties of neural stem cells and their progeny in adult rat subventricular zone. Glia, 57: 136-152. PMID: 18709646
Dill, R.E., E.K. Miller, T. Weil, S. Lesley and G.R. Farmer et al., 1993. Phenytoin increases gene expression for platelet-derived growth factor B chain in macrophages and monocytes. J. Periodontol., 64: 169-173. PMID: 8463938

Doetsch, F., L. Petreanu, I. Caille, J.M. Garcia-Verdugo and A. Alvarez-Buylla 2002. EGF converts transitamplifying neurogenic precursors in the adult brain into multipotent stem cells. Neuron, 36: 10211034. PMID: 12495619

Dragunow, M., J.M. Greenwood, R.E. Cameron, P.J. Narayan and S.J. O'Carroll et al., 2006. Valproic acid induces caspase 3-mediated apoptosis in microglial cells. Neuroscience, 140: 1149-1156. PMID: 16600518

Escueta, A.V. and S.H. Appel, 1971. Diphenylhydantoin and potassium transport in isolated nerve terminals. J. Clin. Invest., 50: 19771984. PMID: 4254679

Eyer, F., N. Felgenhauer, R. Pfab, K. Thurmel and T. Zilker, 2008. Treatment of severe intravenous phenytoin overdose with hemodialysis and hemoperfusion. Med. Sci. Monit., 14: CS145CS148. PMID: 19043374

Falconer, E.M. and L.A. Galea, 2003. Sex differences in cell proliferation, cell death and defensive behavior following acute predator odor stress in adult rats. Brain Res., 975: 22-36. PMID: 12763590

Flores, A.I., S.P. Narayanan, E.N. Morse, H.E. Shick and X. Yin et al., 2008. Constitutively active Akt induces enhanced myelination in the CNS. J. Neurosci., 28: 7174-7183. PMID: 18614687

Frinchi, M., A. Bonomo, A. Trovato-Salinaro, D.F. Condorelli and K. Fuxe et al., 2008. Fibroblast growth factor-2 and its receptor expression in proliferating precursor cells of the subventricular zone in the adult rat brain. Neurosci Lett., 447: 2025. PMID: 18835325

Garcia-Verdugo, J.M., F. Doetsch, H. Wichterle, D.A. Lim and A. Alvarez-Buylla, 1998. Architecture and cell types of the adult subventricular zone: In search of the stem cells. J. Neurobiol., 36: 234-248. PMID: 9712307

Gonzalez-Perez, O., R. Romero-Rodriguez, M. Soriano-Navarro, J.M. Garcia-Verdugo and A. Alvarez-Buylla, 2009. Epidermal growth factor induces the progeny of subventricular zone type B cells to migrate and differentiate into oligodendrocytes. Stem Cells, 27: 2032-2043. PMID: 19544429

Gonzalez-Perez, O., 2010. Immunological regulation of the central nervous system: From physiological to pathological processes. Curr Immunol Rev., 6: 3149. PMID: 21331350 
Gonzalez-Perez, O. and A. Alvarez-Buylla, 2011. Oligodendrogenesis in the subventricular zone and the role of epidermal growth factor. Brain Res. Rev., 67: 147-156. PMID: 21236296

Gonzalez-Perez, O., O. Chavez-Casillas, F. JaureguiHuerta, V. Lopez-Virgen and J. Guzman-Muniz et al., 2011. Stress by noise produces differential effects on the proliferation rate of radial astrocytes and survival of neuroblasts in the adult subgranular zone. Neurosci. Res., 70: 243-250. PMID: 21514330

Gonzalez-Perez, O., A. Quinones-Hinojosa and J.M. Garcia-Verdugo, 2010. Immunological control of adult neural stem cells. J. Stem Cells, 5: 23-31. PMID: 20861925

Grenader, T., M. Gipps, L. Shavit and A. Gabizon, 2007. Significant drug interaction: Phenytoin toxicity due to erlotinib. Lung Cancer, 57: 404406. PMID: 17383767

Iacopino, A.M., D. Doxey, C.W. Cutler, S. Nares, K. Stoever and J. Fojt et al., 1997. Phenytoin and cyclosporine A specifically regulate macrophage phenotype and expression of platelet-derived growth factor and interleukin-1 in vitro and in vivo: possible molecular mechanism of drug-induced gingival hyperplasia. J. Periodontol., 68: 73-83. PMID: 9029455

Jenkins, R.B. and A.C. Ratner, 1972. Diphenylhydantoin and acne. N. Engl. J. Med., 287: 3-148. PMID: 4260678

Jorissen, R.N., F. Walker, N. Pouliot, T.P. Garrett and C.W. Ward et al., 2003. Epidermal growth factor receptor: Mechanisms of activation and signalling. Exp. Cell Res., 284: 31-53. PMID: 12648464

Jqamadze, D., J. Bergen, D. Stone, J.H. Jang and D.V. Schaffer et al., 2012. Colloids as mobile sustratos for the implantation and differentiation neurons into the mammalian brain. Plos One., 7: e30293e30293. PMID: 22295079

Kaindl, A.M., S. Asimiadou, D. Manthey, M.V. Hagen and L. Turski et al., 2006. Antiepileptic drugs and the developing brain. Cell Mol. Life Sci., 63: 399413. PMID: 16389461

Kantarci, A., P. Augustin, E. Firatli, M.C. Sheff and H. Hasturk et al., 2007. Apoptosis in gingival overgrowth tissues. J. Dent. Res., 86: 888-892. PMID: 17720861

Kee, N., S. Sivalingam, R. Boonstra and J.M. Wojtowicz, 2002. The utility of Ki-67 and BrdU as proliferative markers of adult neurogenesis. J. Neurosci. Methods, 115: 97-105. PMID: 11897369

Koyama, H., O. Nakade, T. Saitoh, T. Takuma and T. Kaku 2000. Evidence for the involvement of bone morphogenetic protein-2 in phenytoin-stimulated osteocalcin secretion in human bone cells. Arch. Oral. Biol., 45: 647-655. PMID: 10869476
Kuru, L., S. Yilmaz, B. Kuru, K.N. Kose and U. Noyan, 2004. Expression of growth factors in the gingival crevice fluid of patients with phenytoin-induced gingival enlargement. Arch Oral. Biol., 49: 945950. PMID: 15353252

Lau, K.H., O. Nakade, B. Barr, A.K. Taylor and K. Houchin et al., 1995. Phenytoin increases markers of osteogenesis for the human species in vitro and in vivo. J. Clin. Endocrinol. Metab., 80: 2347-2353. PMID: 7629228

Mackay-Sim, A., 2010. Stem cells and their niche in the adult olfactory mucosa. Arch Ital Biol., 148: 47-58. PMID: 20830968

Ming, G.L. and H. Song, 2005. Adult neurogenesis in the mammalian central nervous system. Ann. Rev. Neurosci., 28: 223-250. PMID: 16022595

Modeer, T. and G. Andersson, 1990. Regulation of epidermal growth factor receptor metabolism in gingival fibroblasts by phenytoin in vitro. J. Oral. Pathol. Med., 19: 188-191. PMID: 2366206

Mowery, T.M., A.L. McDowell and P.E. Garraghty, 2008. Chronic developmental exposure to phenytoin has long-term behavioral consequences. Int. J. Dev. Neurosci., 26: 401-407. PMID: 18455350

Nakade, O., D.J. Baylink and K.H. Lau, 1996. Osteogenic actions of phenytoin in human bone cells are mediated in part by TGF-beta 1 . J Bone Miner Res., 11: 1880-1888. PMID: 8970889

Nichols, N.R., D. Agolley, M. Zieba and N. Bye, 2005. Glucocorticoid regulation of glial responses during hippocampal neurodegeneration and regeneration. Brain Res. Brain Res. Rev., 48: 287-301. PMID: 15850668

Ogura, H., M. Yasuda, S. Nakamura, H. Yamashita and Mikoshiba et al., 2002. Neurotoxic damage of granule cells in the dentate gyrus and the cerebellum and cognitive deficit following neonatal administration of phenytoin in mice. J. Neuropathol. Exp. Neurol., 61: 956-967. PMID: 12430712

Ohmori, H., H. Ogura, M. Yasuda, S. Nakamura and T. Hatta et al., 1999. Developmental neurotoxicity of phenytoin on granule cells and Purkinje cells in mouse cerebellum. J. Neurochem., 72: 1497-1506. PMID: 10098854

Ohta, T., J.E. Wergedal, T. Matsuyama, D.J. Baylink and K.H. Lau, 1995. Phenytoin and fluoride act in concert to stimulate bone formation and to increase bone volume in adult male rats. Calcif Tissue Int., 56: 390-397. PMID: 7621347 
Okada, K, T. Sugiura, E. Kuroda, S. Tsuji and U. Yamashita, 2001. Phenytoin promotes Th2 type immune response in mice. Clin Exp. Immunol 124: 406-413. PMID: 11472401

Okada, M., Y. Kawata, K. Kiryu, K. Mizuno and K. Wada et al., 1997. Effects of non-toxic and toxic concentrations of phenytoin on monoamines levels in rat brain. Epilepsy Res., 28: 155-163. PMID: 9267780

Putignano, P., G.A. Kaltsas, M.A. Satta and A.B. Grossman, 1998. The effects of anti-convulsant drugs on adrenal function. Horm. Metab. Res., 30: 389-397. PMID: 9694568

Sahay, A. and R. Hen, 2008. Hippocampal neurogenesis and depression. Novartis Found Symp., 289: 152-160. PMID: 18497101

Saito, K., S Mori, M. Iwakura and S. Sakamoto, 1996. Immunohistochemical localization of transforming growth factor beta, basic fibroblast growth factor and heparan sulphate glycosaminoglycan in gingival hyperplasia induced by nifedipine and phenytoin. J. Periodontal. Res., 31: 545-555. PMID: 8971653

Sanai, N., A.D. Tramontin, A. Quinones-Hinojosa, N.M. Barbaro and N. Gupta et al., 2004. Unique astrocyte ribbon in adult human brain contains neural stem cells but lacks chain migration. Nature, 427: 740-744. PMID: 14973487

Sano, M., N. Ohuchi, T. Inoue, K. Tono and T. Tachikawa et al., 2004. Proliferative response to phenytoin and nifedipine in gingival fibroblasts cultured from humans with gingival fibromatosis. Fundam. Clin. Pharmacol., 18: 465-470. PMID: 15312153

Sasaki, T. and E. Maita, 1998. Increased bFGF level in the serum of patients with phenytoin-induced gingival overgrowth. J. Clin. Periodontol., 25: 4247. PMID: 9477019

Seri, B., J.M. Garcia-Verdugo, L. Collado-Morente, B.S. McEwen and A. Alvarez-Buylla, 2004. Cell types, lineage and architecture of the germinal zone in the adult dentate gyrus. J. Comput. Neurol., 478: 359-378. PMID: 15384070

Seri, B., D.G. Herrera, A. Gritti, S. Ferron, L. Collado and A. Vescovi et al., 2006. Composition and organization of the SCZ: A large germinal layer containing neural stem cells in the adult mammalian brain. Cereb. Cortex, 1: 103-111. PMID: 16766696

Shaw, J., C.M. Hughes, K.M. Lagan and P.M. Bell, 2007. The clinical effect of topical phenytoin on wound healing: A systematic review. Br. J. Dermatol., 157: 997-1004. PMID: 17854378
Soory, M. and S.C. Kasasa, 1997. The effects of epidermal growth factor, interleukin-1 and phenytoin, alone and in combination, on C19 steroid conversions in fibroblasts. J. Periodontol., 68: 819-826. PMID: 9379324

Swamy, S.M., P. Tan, Y.Z. Zhu, J. Lu and H.N. Achuth et al., 2004. Role of phenytoin in wound healing: microarray analysis of early transcriptional responses in human dermal fibroblasts. Biochem Biophys Res. Commun., 314: 661-666. PMID: 14741686

Taupin, P., 2007. BrdU immunohistochemistry for studying adult neurogenesis: Paradigms, pitfalls, limitations and validation. Brain Res. Rev., 53: 198-214. PMID: 17020783

Turan, M., S.U. Saraydyn, H.E. Bulut, S. Elagoz and O. Cetinkaya et al., 2004. Do vascular endothelial growth factor and basic fibroblast growth factor promote phenytoin's wound healing effect in rat? An immunohistochemical and histopathologic study. Dermatol. Surg., 30: 1303-1309. PMID: 15458527

Vivard, I., P. Trechot, J.L. Schmutz, J.F. Cuny and M. Weber et al., 1989. [Phenytoin and hirsutism]. Ann. Dermatol. Venereol., 116: 8-562. PMID: 2596801

Vazquez, I.P., M.O. Macias and I.M. Herranz, 2003. [Phenytoin: Paradoxical toxicity; a discussion of 4 cases]. Farm Hosp, 27: 386-390. PMID: 14974884

Warner-Schmidt, J.L and R.S. Duman, 2006. Hippocampal neurogenesis: Opposing effects of stress and antidepressant treatment. Hippocampus, 16: 239-249. PMID: 16425236

Yang, J., C. Wetterstrand and R.S. Jones, 2007. Felbamate but not phenytoin or gabapentin reduces glutamate release by blocking presynaptic NMDA receptors in the entorhinal cortex. Epilepsy Res., 77: 157-164. PMID: 17980555

Zhang, S.Q., W.G. Tsiaras, T. Araki, G. Wen and L. Minichiello et al., 2002. Receptor-specific regulation of phosphatidylinositol 3'-kinase activation by the protein tyrosine phosphatase Shp2. Mol. Cell Biol., 22: 4062-4072. PMID: 12024020

Zhao, L.Z., X.W. Su, Y.J. Huang, P.X. Qiu and G.M. Yan, 2003. Activation of c-Jun and suppression of phospho-p44/42 were involved in diphenylhydantoin-induced apoptosis of cultured rat cerebellar granule neurons. Acta Pharmacol. Sin., 24: 539-548. PMID: 12791180

Zhou, X., Y.M. Li, W.J. Ji, T.M. Jiang and X.N. Sun et al., 2006. Phenytoin can accelerate the healing process after experimental myocardial infarction. Int. J. Cardiol., 107: 21-29. PMID: 15996772 